\title{
KAJIAN VALIDITAS INSTRUMEN PENGUKURAN SKALA PENGALAMAN KERAWANAN PANGAN DI INDONESIA*
}

\author{
Herlina $^{1}$, Bagus Sartono ${ }^{2 \ddagger}$, and Budi Susetyo ${ }^{3}$ \\ 1Badan Pusat Statistik, Indonesia, ummiaddina@gmail.com \\ 2Department of Statistics, IPB University, Indonesia, bagusco@gmail.com \\ ${ }^{3}$ Department of Statistics, IPB University, Indonesia, buset008@yahoo.com \\ Fcorresponding author
}

Indonesian Journal of Statistics and Its Applications (eISSN:2599-0802)

Vol 4 No 1 (2020), 136 - 155

Copyright @ 2020 Herlina, Bagus Sartono, and Budi Susetyo. This is an open-access article distributed under the Creative Commons Attribution License, which permits unrestricted use, distribution, and reproduction in any medium, provided the original work is properly cited.

\begin{abstract}
The results of the FAO study since 2013 through the Voices of Hungry Project (VoHFAO) have produced measures of the Food Insecurity Experience Scale (FIES). FIES is a global reference scale that becomes a reference for comparing the prevalence of food insecurity between countries and regions. The challenge of using the FIES instrument, each country must carry out linguistic adaptations that are appropriate to the culture and national language. This study aims to analyze the validity of FIES measurements in Indonesia, including internal and external analysis. The Rasch model (RM) used for internal validity analysis. Measurement of the validity and reliability of Indonesian FIES items was calibrated with a global reference scale. Differences in the scale of calibration items with a global reference scale of less than 0.35 indicate that they are standard items. FIES measurements require at least five common items. External analysis of FIES measurements uses the Pearson correlation between districtlevel aggregation on each FIES item that is answered "yes" and determinant characteristics of household food insecurity. The expected correlation coefficient indicated the direction of a positive correlation and observed the correlation coefficient of item 1501 to 1508 , which is getting smaller. Internal analysis of FIES measurements in Indonesia shows the achievement of unidimensional and local independence assumptions. However, item 1501 has identified as an outlier. Then identify unique issues are 1501 and 1504, while unique items in rural subsamples are 1503 and 1508. Unique item differences founded in food expenditure 60 percent or more, i.e., 1502. This shows a discordance with items assumption of parameter invariance. The reliability of the FIES item is 0.78 , and this reflects the suitability of the model quite well. External analysis of the FIES measurement identifies item 1501 and 1504 as invalid items (unique items).
\end{abstract}

Keywords: calibration, food insecurity experience scale, pearson, rasch model.

* Received Aug 2019; Accepted Feb 2020; Published online on Feb 2020 


\section{Pendahuluan}

Kerawanan pangan merupakan suatu kondisi ketidakmampuan individu dan rumah tangga untuk memperoleh pangan yang memadai dan dan bergizi. Pemerintah turut bertanggung jawab dalam pemenuhannya dan tercantum dalam Undang-Undang No. 18 Tahun 2012 tentang Pangan (DKP, 2015). Undang-undang tersebut mendefinisikan ketahanan pangan sebagai kondisi terpenuhinya pangan yang cukup, beragam jenisnya dan bergizi serta menjangkau bagi seluruh rakyat.

Pada Deklarasi Konferensi Tingkat Tinggi Dunia tahun 2009, Food Agriculture Organization (FAO) merevisi konsep ketahanan pangan untuk memperjelas indikator akses pangan. Ketahanan pangan berwujud tersedianya akses fisik, sosial dan ekonomi untuk mendapatkan makanan yang memadai, bergizi dan beragam. Hal ini bertujuan agar setiap orang memiliki kehidupan yang aktif dan sehat (FAO, 2009). Dengan demikian, dimensi ketahananan pangan meliputi ketersediaan pangan, akses mendapatkan pangan, dan pemanfaatan pangan.

FAO menginisiasi pengukuran kerawanan pangan menggunakan pendekatan akses untuk mendapatkan makanan. Hasil studi FAO sejak tahun 2013 melalui Voices of Hungry Project (VoH-FAO) menghasilkan pengukuran Skala Pengalaman Kerawanan Pangan (Food Insecurity Experience Scale/FIES). Ballard et al. (2013) memaparkan bahwa instrumen FIES merupakan akumulasi dari dua skala ketahanan pangan berbasis pengalaman yang telah divalidasi. Cafiero et al. (2018) memaparkan bahwa pengumpulan data FIES dilakukan oleh Gallup World Poll (GWP) sejak tahun 2014 sampai tahun 2016 di 153 negara atau wilayah dan menghasilkan skala referensi global FIES (The FIES Global Standard Scale). Skala tersebut berguna untuk memvalidasi butir FIES dan menetapkan reliabilitas pada pengukuran skala FIES yang dilakukan oleh masing-masing negara. Butir yang valid digunakan untuk mengukur prevalensi kerawanan pangan di negara tersebut, dan selanjutnya nilai prevalensi dianalisis keterbandingannya antar negara.

FAO (2018) menyatakan sejak tahun 2017 , terdapat sembilan negara yang mulai menggunakan seluruh butir FIES pada pelaksanaan survei di negaranya. Indonesia termasuk diantaranya yang mengintegrasikan instrumen FIES pada Survei Sosial Ekonomi Rumah Tangga Nasional (SUSENAS) mulai tahun 2017. Gambar 1 merupakan rangkaian pertanyaan butir FIES yang diterjemahkan ke dalam bahasa Indonesia.

Ballard et al. (2013) memaparkan Gambar 1 diatas akan dijawab "ya" pada butir FIES berdasarkan situasi yang pernah dialami responden. Pengalaman ini setidaknya terjadi satu kali dalam setahun terakhir. Penyebab terbatasnya akses karena kurangnya uang atau sumber daya lainnya. Sumber daya lainnya mengacu pada kondisi kurang tersedia sarana lainnya yang biasa dimanfaatkan untuk mendapatkan makanan. FAO (2018) memaparkan sumber daya lain meliputi makanan yang diperoleh dari produksi sendiri termasuk produksi dari kegiatan pertanian yang dapat dijual maupun dikonsumsi sendiri serta kiriman makanan dari pihak luar rumah tangga.

Ballard et al. (2013) menyatakan bahwa responden dimungkinkan membuat kesalahan dalam menyampaikan pengalamannya. Penyebab yang paling mungkin karena kesalahpahaman responden terhadap makna butir FIES. Oleh karena itu, konsep yang mendasari pengukuran FIES meliputi respon terhadap butir dan pembentukan skala pengukuran. Respon terhadap butir dimaksudkan peluang 
responden akan menjawab setiap butir sesuai dengan tingkat keparahan kerawanan pangan yang pernah dialaminya. Semakin parah pengalaman kerawanan pangan responden maka relatif semakin besar peluang untuk menjawab "ya" pada butir FIES. Cafiero et al. (2018) menyatakan bahwa probabilitas untuk menegaskan hal-hal yang kurang parah selalu lebih tinggi daripada yang menegaskan hal-hal yang lebih parah.

\begin{tabular}{|c|c|}
\hline \multicolumn{2}{|c|}{ BLOK XV. AKSES TERHADAP MAKANAN } \\
\hline \multicolumn{2}{|c|}{$\begin{array}{l}\text { SEKARANG SAYA AKAN MENGAJUKAN BEBERAPA PERTANYAAN MENGENAI AKSES TERHADAP MAKANAN. } \\
\text { DALAM SETAHUN TERAKHIR, APAKAH ADA SAAT DIMANA: }\end{array}$} \\
\hline $\begin{array}{l}\text { 1501. SELAMA SETAHUN TERAKHIR, APAKAH ANDA/ART LAINNYA } \\
\text { KHAWATIR TIDAK AKAN MEMILIII CUKUP MAKANAN UNTUK } \\
\text { DISANTAP KARENA KURANGNYA UANG ATAU SUMBER DAYA } \\
\text { LAINNYA? }\end{array}$ & 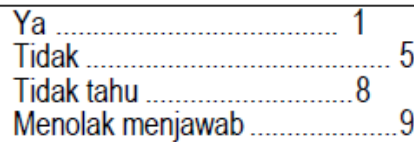 \\
\hline $\begin{array}{l}\text { 1502. SELAMA SETAHUN TERAKHIR, APAKAH ADA SAAT DI MANA } \\
\text { ANDA/ART LAINNYA TIDAK DAPAT MENYANTAP MAKANAN } \\
\text { SEHAT DAN BERGIZI KARENA KURANGNYA UANG ATAU } \\
\text { SUMBER DAYA LAINNYA? }\end{array}$ & 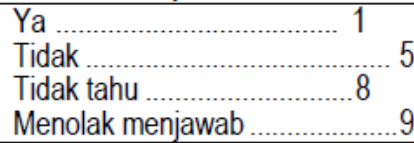 \\
\hline $\begin{array}{l}\text { 1503. SELAMA SETAHUN TERAKHIR, APAKAH ANDA/ART LAINNYA } \\
\text { HANYA MENYANTAP SEDIKIT JENIS MAKANAN KARENA TIDAK } \\
\text { MEMILIKI UANG ATAU SUMBER DAYA LAINNYA? }\end{array}$ & 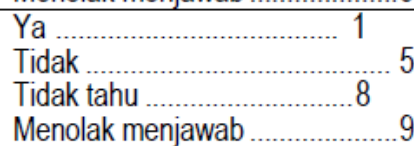 \\
\hline $\begin{array}{l}\text { 1504. SELAMA SETAHUN TERAKHIR, APAKAH ANDA/ART LAINNYA } \\
\text { PERNAH MELEWATKAN MAKAN PADA SUATU HARI TERTENTU } \\
\text { KARENA TIDAK MEMILIKI UANG ATAU SUMBER DAYA LAIN } \\
\text { YANG CUKUP UNTUK MENDAPATKAN MAKANAN? }\end{array}$ & 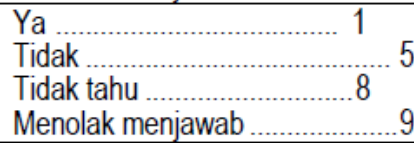 \\
\hline $\begin{array}{l}\text { 1505. SELAMA SETAHUN TERAKHIR, APAKAH ANDA/ART LAINNYA } \\
\text { MAKAN LEBIH SEDIKIT DARIPADA SEHARUSNYA KARENA } \\
\text { KURANGNYA UANG ATAU SUMBER DAYA LAINNYA? }\end{array}$ & 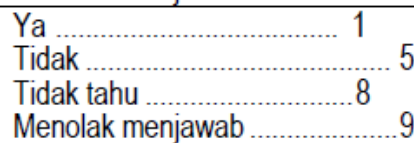 \\
\hline $\begin{array}{l}\text { 1506. SELAMA SETAHUN TERAKHIR, APAKAH RUMAH TANGGA } \\
\text { KEHABISAN MAKANAN KARENA KURANGNYA UANG ATAU } \\
\text { SUMBER DAYA LAINNYA? }\end{array}$ & $\begin{array}{l}\text { Ya } \\
\text { Tidak }\end{array}$ \\
\hline $\begin{array}{l}\text { 1507. SELAMA SETAHUN TERAKHIR, APAKAH ANDA/ART LAINNYA } \\
\text { MERASA LAPAR TAPI TIDAK MAKAN KARENA KURANGNYA UANG } \\
\text { ATAU SUMBER DAYA LAINNYA UNTUK MENDAPATKAN } \\
\text { MAKANAN? }\end{array}$ & 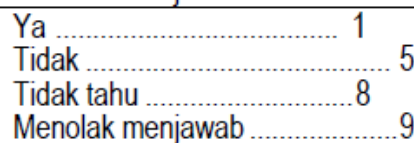 \\
\hline $\begin{array}{l}\text { 1508. SELAMA SETAHUN TERAKHIR, APAKAH ANDA/ART LAINNYA } \\
\text { TIDAK MAKAN SEHARIAN KARENA KURANGNYA UANG ATAU } \\
\text { SUMBER DAYA LAINNYA? }\end{array}$ & 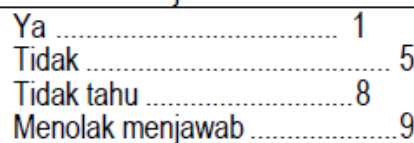 \\
\hline
\end{tabular}

Gambar 1: Pertanyaan FIES dalam kuesioner Kor SUSENAS Maret 2017.

Kajian validitas instrumen FIES di Indonesia belum diteliti. Oleh karena itu, penelitian ini bertujuan untuk menganalisis validitas instrumen FIES, meliputi analisis internal dan eksternal pengukuran FIES. Analisis internal pengukuran FIES menggunakan Rasch Model (RM) yang bertujuan memastikan penduga parameter yang dihasilkan sesuai dengan konstruk teori kerawanan pangan. RM merupakan pendekatan model psikometrik Teori Respon Butir (Item Respon Theory/IRT) model logistik satu parameter. Cafiero et al. (2014), Nord (2014), FAO (2018) menyatakan bahwa RM mampu menduga tingkat keparahan setiap butir berdasarkan respon seluruh responden dengan menerapkan serangkaian uji validitas dan reliabilitas.

\section{Metodologi}

\subsection{Data}

Penelitian menggunakan data Susenas Maret 2017 bersumber dari Badan Pusat Statistik (BPS). Satuan pengamatan dalam penelitian ini adalah rumah tangga yang 
menjawab dengan lengkap seluruh butir FIES. Data yang digunakan meliputi butir FIES dan peubah determinan kerawanan pangan.

Tabel 1: Peubah-peubah yang digunakan dalam penelitian.

\begin{tabular}{|c|c|c|c|}
\hline Peubah & Definisi Peubah & Skala & Penelitian \\
\hline KRT rawan $(\mathrm{X} 1)$ & $\begin{array}{l}\text { Kepala rumah tangga perempuan } \\
\text { yang memiliki ART berusia } 0-14 \text { tahun }\end{array}$ & $\begin{array}{l}\text { Nominal } \\
\text { 1. Ya } \\
0 . \text { Tidak }\end{array}$ & $\begin{array}{l}\text { (Magaña-Lemus } \\
\text { et al., 2016) } \\
\text { (Wardani, 2018) }\end{array}$ \\
\hline JART-014 (X2) & $\begin{array}{l}\text { Jumlah anggota rumah tangga } \\
\text { berusia } 0-14 \text { tahun }\end{array}$ & Rasio & $\begin{array}{l}\text { (Magaña-Lemus } \\
\text { et al., 2016) } \\
\text { (Wambogo et al., } \\
\text { 2018) }\end{array}$ \\
\hline Air tidak layak (X3) & $\begin{array}{l}\text { Air Tidak Layak adalah air yang } \\
\text { bukan bersumber dari leding } \\
\text { eceran/meteran dan pompa/sumur } \\
\text { terlindung/mata air terlindung. } \\
\text { Sumber air tersebut berjarak kurang } \\
10 \mathrm{~m} \text { ke tempat penampungan } \\
\text { kotoran/tinja }\end{array}$ & $\begin{array}{l}\text { Nominal } \\
\text { 1. Ya } \\
0 . \text { Tidak }\end{array}$ & $\begin{array}{l}\text { (DKP, 2015) } \\
\text { (BPS, 2017a) } \\
\text { (BPS, 2017b) }\end{array}$ \\
\hline $\begin{array}{l}\text { Sanitasi tidak layak } \\
\text { (X4) }\end{array}$ & $\begin{array}{l}\text { Tidak tersedianya fasilitas layak untuk } \\
\text { membuang kotoran dan bahan } \\
\text { buangan berbahaya lainnya }\end{array}$ & $\begin{array}{l}\text { Nominal } \\
\text { 1. Ya } \\
\text { 0. Tidak }\end{array}$ & $\begin{array}{l}\text { (DKP, 2015) } \\
\text { (BPS, 2017a) } \\
\text { (Alexandri, 2015) }\end{array}$ \\
\hline KPS (X5) & $\begin{array}{l}\text { Responden memiliki Kartu } \\
\text { Perlindungan Sosial }\end{array}$ & $\begin{array}{l}\text { Nominal } \\
\text { 1. Ya } \\
\text { 0. Tidak }\end{array}$ & $\begin{array}{l}\text { (Smith et al., } \\
\text { 2017) (Wardani, } \\
\text { 2018) }\end{array}$ \\
\hline PJS (X6) & $\begin{array}{l}\text { BPJS Kesehatan dimana iurannya } \\
\text { ditanggung oleh pemerintah }\end{array}$ & $\begin{array}{l}\text { Nominal } \\
\text { 1. Ya } \\
\text { 0. Tidak }\end{array}$ & $\begin{array}{l}\text { (Smith et al., } \\
\text { 2017) (Wardani, } \\
\text { 2018) }\end{array}$ \\
\hline Raskin (X7) & $\begin{array}{l}\text { Responden merupakan penerima } \\
\text { bantuan beras miskin dari pemerintah }\end{array}$ & $\begin{array}{l}\text { Nominal } \\
\text { 1. Ya } \\
\text { 0. Tidak }\end{array}$ & $\begin{array}{l}\text { (Smith et al., } \\
\text { 2017) (Sundari \& } \\
\text { Nachrowi, 2015) }\end{array}$ \\
\hline Tidak KUR (X8) & $\begin{array}{l}\text { Responden tidak memiliki akses } \\
\text { terhadap Kredit Usaha Rakyat/KUR }\end{array}$ & $\begin{array}{l}\text { Nominal } \\
\text { 1. Ya } \\
\text { 0. Tidak }\end{array}$ & $\begin{array}{l}\text { (Smith et al., } \\
\text { 2017) }\end{array}$ \\
\hline $\begin{array}{l}\text { Pengeluaran } \\
\text { perkapita }(X 10)\end{array}$ & $\begin{array}{l}\text { Pengeluaran rata-rata sebulan untuk } \\
\text { setiap anggota rumah tangga }\end{array}$ & Rasio & $\begin{array}{l}\text { (Smith et al., } \\
\text { 2017) }\end{array}$ \\
\hline $\begin{array}{l}\text { Penerima transfer } \\
(\mathrm{X} 11)\end{array}$ & $\begin{array}{l}\text { Pembiayaan sebagian besar } \\
\text { kebutuhan hidupnya berasal dari } \\
\text { kiriman uang atau barang dari orang } \\
\text { diluar anggota rumah tangga }\end{array}$ & $\begin{array}{l}\text { Nominal } \\
\text { 1. Ya } \\
\text { 0. Tidak }\end{array}$ & $\begin{array}{l}\text { (Smith et al., } \\
\text { 2017) (Wardani, } \\
\text { 2018) }\end{array}$ \\
\hline PPP (X12) & $\begin{array}{l}\text { Persentase pengeluaran untuk } \\
\text { pangan terhadap total pengeluaran } \\
\text { rumah tangga }\end{array}$ & Rasio & $\begin{array}{l}\text { (Sundari \& } \\
\text { Nachrowi, 2015) }\end{array}$ \\
\hline Pangan GKM (X13) & $\begin{array}{l}\text { Pengeluaran makanan perkapita } \\
\text { sama atau lebih kecil dari Garis } \\
\text { Kemiskinan Makanan Provinsi }\end{array}$ & $\begin{array}{l}\text { Nominal } \\
\text { 1. Ya } \\
\text { 0. Tidak }\end{array}$ & $\begin{array}{l}\text { (Duffy \& Zizza, } \\
2016) \\
\text { (Smith et al., } \\
\text { 2017) (Magaña- } \\
\text { Lemus et al., } \\
\text { 2016) }\end{array}$ \\
\hline
\end{tabular}


Butir FIES terdiri dari delapan butir yang menunjukkan urutan pengalaman kesulitan rumah tangga untuk akses mendapatkan makanan karena kurangnya uang atau sumber daya lainnya. Butir 1501 merupakan pengalaman kekhawatiran rumah tangga tidak akan memiliki cukup makanan (worried). Butir 1502 tentang pengalaman rumah tangga tidak bisa menyantap makanan sehat dan bergizi (healthy). Butir 1503 tentang pengalaman menyantap sedikit jenis makanan (fewfood). Butir 1504 tentang melewatkan satu kali waktu makan (skipped). Butir 1505 tentang makan lebih sedikit dari yang dibutuhkan (ateless). Butir 1506 tentang kehabisan makanan atau tidak memiliki sedikitpun makanan (runout). Butir 1507 tentang pengalaman fisik merasa lapar namun tidak mendapatkan makanan (hungry). Butir 1508 merupakan pengalaman responden selama seharian tidak mengkonsumsi makanan apapun (wholeday).

Pada setiap butir disediakan empat pilihan jawaban, sebagai berikut:

- Rumah tangga menjawab kode 1 jika pernah mengalami keadaan tersebut.

- Rumah tangga menjawab kode 5 jika tidak pernah mengalami keadaan tersebut.

- Rumah tangga menjawab kode 8 jika tidak mengetahui keadaan tersebut.

- Rumah tangga menjawab kode 9 jika menolak menjawab.

Determinan kerawanan pangan ditampilkan pada Tabel 1. Hal ini merujuk hasil penelitian kerawanan pangan rumah tangga terdahulu.

\subsection{Metode Penelitian}

Tahapan analisis data yang dilakukan dalam penelitian, sebagai berikut :

1. Penyiapan data dengan mengganti kode pada peubah FIES rincian 1501 sampai dengan 1508. Kode 1 tetap, kode 5 diubah menjadi 0 dan kode 8 serta 9 tidak digunakan dalam analisis. Perlakuan yang sama diterapkan pada data kosong (missing value). Oleh karena itu, data yang digunakan dalam penelitian ini bersumber dari rumah tangga yang merespon seluruh butir FIES.

2. Eksplorasi data mentah butir FIES dengan menganalisis persentase respon "ya" pada setiap butir FIES.

3. Pengolahan data FIES menggunakan Rasch Model Conditional Maximum Lilkelihood (RM-CML) menggunakan penimbang rumah tangga dan prosedur pendugaan parameter menggunakan algoritma Quasi Newton-Raphson (QN).

Rasch Model (RM) merupakan teori respon butir dengan satu parameter logistik (One Parameter Logistics Model). RM biasa digunakan dalam pengukuran di bidang pendidikan dan psikologi. RM mampu menilai kesesuaian serangkaian butir dengan konstruk teori yang mendasari pengukuran, membuat skala butir dan membandingkan kinerja skala dalam berbagai populasi (Ballard et al., 2013; Nord, 2014).

RM pertama kali dikembangkan oleh George Rasch pada tahun 1960. Rasch memberikan dua buah tes kepada siswa kelas 4 sampai dengan kelas 6 SD. Hasil tes menyimpulkan peluang siswa menjawab soal dengan benar tergantung perbedaan antara kemampuan siswa dengan tingkat kesulitan soal (Bond \& Fox, 2015). Gagasan Rasch tersebut menunjukkan peluang siswa dengan kemampuan tertentu $\left(\theta_{j}\right)$ merespon dengan benar pada soal dengan tingkat kesulitan tertentu $\left(\beta_{i}\right)$. Hal ini dimodelkan dengan fungsi logistik jarak antara $\theta_{j}$ dan $\beta_{i}$, sebagai berikut: 


$$
\frac{P}{1-P}=e^{\left(\theta_{j}-\beta_{i}\right)}
$$

Persamaan 1 menunjukkan $P$ sebagai nilai peluang siswa ke-j menjawab benar pada soal ke-i. Sedangkan (1- $P$ ) merupakan peluang siswa ke-j menjawab salah pada soal ke-i, $e$ adalah basis logaritma natural, $\theta_{j}$ menunjukkan penduga parameter tingkat kemampuan siswa dan $\beta_{i}$ menunjukkan penduga parameter tingkat kesulitan butir soal.

4. Menganalisis kesesuaian penduga parameter tingkat keparahan butir $\left(\beta_{i}\right)$ dengan konstruk teori pengukuran pengalaman kerawanan pangan menggunakan kurva karakteristik butir.

Analisis skala keparahan butir $\left(b_{i}\right)$ menggunakan Kurva Karakteristik Butir (Item Characteristics Curve/ICC). ICC menunjukkan hubungan antara peluang responden menjawab ya $(\operatorname{Pi}(\theta))$ dengan skala kemampuan responden $(\theta)$. Hambleton et al. (1991) menyatakan ICC sebagai hubungan matematis antara peluang responden dengan kemampuan tertentu mampu menjawab benar pada butir soal. Cafiero et al. (2017) memaparkan ICC sebagai berikut:

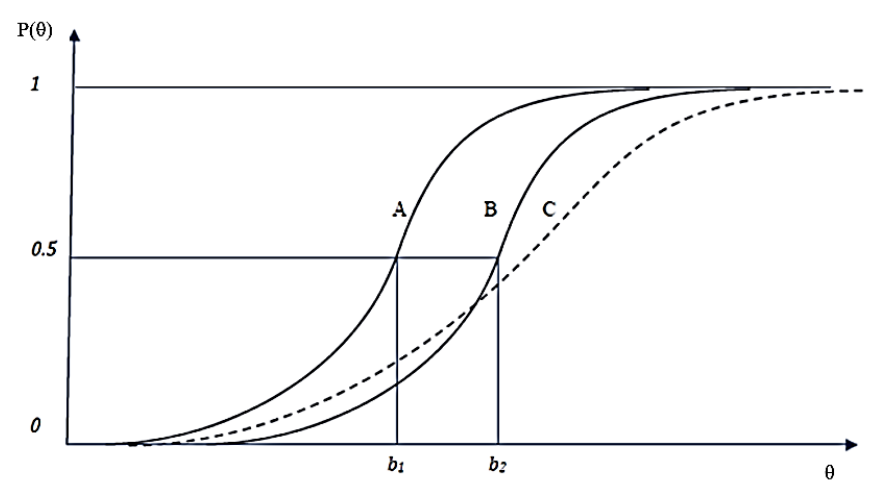

Gambar 2: Kurva karakteristik butir.

Gambar 2 merupakan kurva karakteristik butir dalam konteks kerawanan pangan. Pada sumbu $x$ menunjukkan skala kemampuan responden, atau dinyatakan sebagai skala tingkat keparahan kerawanan pangan responden $(\theta)$. Sumbu $y$ menunjukkan peluang responden menjawab "ya" pada suatu butir FIES $\left(P_{i}(\theta)\right)$. Skala tingkat kesukaran butir $\left(b_{i}\right)$ dinyatakan sebagai skala keparahan butir yang menunjukkan pengalaman kesulitan responden dalam akses mendapatkan makanan. Skala tersebut ditunjukkan pada saat $\theta$ memiliki peluang menjawab "ya" sebesar 0.5 .

5. Menganalisis validitas internal butir FIES meliputi nilai fit statistics (infit, outfit, dan korelasi residual) serta koefisien reliabilitas.

FAO (2018) memaparkan pengukuran validitas butir FIES dengan menilai konsistensi data dengan asumsi RM. Jika asumsi terpenuhi menandakan pengukuran FIES dapat digunakan untuk menghitung prevalensi kerawanan pangan. Hal ini merupakan pengukuran validitas internal butir FIES.

FAO (2018) dan Ballard et al. (2013) mencantumkan asumsi RM dalam pengukuran FIES, sebagai berikut: 
- Semakin parah pengalaman kerawanan pangan responden, maka semakin tinggi peluangnya untuk menjawab "ya" pada suatu butir. Hal ini ditunjukkan oleh kurva karakteristik butir.

- Unidimensi yakni hanya mengukur kemampuan responden yang diwakili data respon tentang pengalaman akses untuk mendapatkan makanan.

- Independensi lokal yang menunjukkan bahwa jawaban responden ke-j pada suatu butir bersifat independen terhadap jawaban responden pada butir lainnya. Hal ini ditunjukkan oleh korelasi residual antar butir yang bernilai kecil, sehingga diinterpretasikan bahwa jawaban responden pada suatu butir tidak memengaruhi jawaban responden pada butir yang lain.

- Invariansi parameter dimana semua butir terkait dengan sifat laten kerawanan pangan namun berbeda dalam tingkat keparahannya. Hal ini terbukti jika parameter butir yang valid tidak berbeda walaupun diujikan pada kelompok responden yang berbeda kemampuannya.

Nord (2014) menyatakan data yang memenuhi asumsi tersebut menunjukkan bahwa skor mentah rumah tangga merupakan data ordinal dari penduga parameter tingkat kesulitan butir. Responden dengan skor mentah bernilai 6 hanya menunjukkan keadaan yang lebih tidak aman dibandingkan dengan skor mentah bernilai 3. Namun, tidak dapat digunakan untuk menyatakan perbedaan diantara kedua skor tersebut. Penduga parameter tingkat keparahan kerawanan pangan responden dapat menginformasikan perbedaan tersebut secara kuantitatif menggunakan pengukuran prevalensi kerawanan pangan rumah tangga.

Validasi dengan RM menghasilkan statistik kesesuaian model (fit statistics) yang memberikan keterangan mengenai kesesuaian dari asosiasi setiap butir dengan sifat laten yang mendasarinya. Fit statistics meliputi nilai infit dan outfit yang menunjukkan kekuatan dan konsistensi asosiasi dari setiap butir dengan sifat laten yang mendasarinya (Carlo Cafiero et al., 2014). Nord (2014) menyatakan fit statistics menggunakan pendekatan Chi-Square yakni dengan membandingkan respon aktual dengan respon probabilistik dari setiap sel matriks rumah tangga per butir. Infit butir menggunakan rumus berikut:

$$
\text { Infit }_{i}=\sum_{i=1}^{k}\left[\left(u_{i j}-P_{i j}\right)^{2}\right] / \sum_{i=1}^{k}\left(P_{i j}-P_{i j}{ }^{2}\right)
$$

Outfit butir menggunakan rumus berikut:

$$
\text { Outfit } t_{i}=\sum_{i=1}^{k}\left[\left(u_{i j}-P_{i j}\right)^{2} / P_{i j}-P_{i j}^{2}\right] / n
$$

Persamaan (11) dan (12) menggunakan $u_{i j}$ sebagai respon yang diberikan rumah tangga ke-j pada butir ke-i; $P_{i j}$ merupakan peluang respon rumah tangga ke-j pada butir ke-i dibawah asumsi RM; dan $\mathrm{n}$ adalah jumlah rumah tangga sampel. Selain itu, diperoleh nilai korelasi residual untuk menguji asumsi independensi lokal RM.

6. Melakukan kalibrasi skala butir FIES Indonesia dengan skala referensi global (global reference scale). Selanjutnya ditetapkan butir FIES yang termasuk umum (valid) dan butir unik (tidak valid).

7. Melakukan pengujian asumsi invariansi penduga parameter tingkat kesulitan butir pada subsampel rumah tangga yang berbeda. Subsampel yang dimaksud meliputi 
wilayah tempat tinggal dan pangsa pengeluaran pangan. Prosedurnya mengikuti tahapan pada poin 3 sampai 6 .

8. Menganalisis validitas eksternal butir FIES menggunakan korelasi Pearson antara nilai agregasi kabupaten/kota pada setiap butir FIES yang berkode $1(Y)$ dengan karakteristik determinan kerawanan pangan rumah tangga (X).

Ballard et al. (2013) menyatakan bahwa tidak ada indikator tunggal untuk menjelaskan dimensi keamanan pangan dan gizi. Analisis butir FIES dengan determinan kerawanan pangan diharapkan menunjukkan konsistensi antara jawaban responden dengan karakteristik rumah tangganya. Hal ini ditunjukkan oleh nilai koefisien korelasi yang semakin kecil pada butir FIES yang semakin parah.

Korelasi antara butir FIES yang dijawab "ya" dengan peubah determinan kerawanan pangan merupakan pengamatan berpasangan pada data sampel rumah tangga. Analisis menggunakan korelasi Pearson dengan persamaan berikut:

$$
r_{x y}=\frac{\sum_{i=1}^{n}\left(x_{i}-\bar{x}\right)\left(y_{i}-\bar{y}\right)}{\sqrt{\sum_{i=1}^{n}\left(x_{i}-\bar{x}\right)^{2}} \sqrt{\sum_{i=1}^{n}\left(y_{i}-\bar{y}\right)^{2}}}
$$

Persamaan diatas menunjukkan $r_{x y}$ merupakan koefisien korelasi $\mathrm{x}$ dan $\mathrm{y}$. Koefisien korelasi bernilai -1 sampai 1 dan memiliki arah korelasi positif atau negatif. Nilai koefisien semakin mendekati 1 atau -1 menunjukkan korelasi yang semakin kuat antara peubah $X$ dengan $Y$. Koefisien korelasi positif bermakna nilai $X$ yang besar berkorelasi dengan nilai $Y$ yang besar pula, begitu pun sebaliknya. Korelasi negatif menunjukkan nilai $X$ yang besar berasosiasi dengan nilai $Y$ yang kecil, begitu pun sebaliknya.

\section{Hasil dan Pembahasan}

\subsection{Eksplorasi Data FIES}

Pengukuran FIES menggunakan Rasch Model mensyaratkan respon yang lengkap responden (rumah tangga). Pada penelitian ini terdapat 2.31 persen sampel rumah tangga yang tidak merespon seluruh butir FIES. Berdasarkan butir FIES yang tidak direspon lengkap, diketahui butir 1502 paling banyak tidak direspon (38.33 persen) dan butir 1508 paling sedikit tidak direspon lengkap (20.65 persen). 
Butir FIES menunjukkan situasi yang berbeda berdasarkan urutan kerawanan pangan yang dialami responden (Ballard et al., 2013). Oleh karena itu, setiap butir FIES yang dijawab "ya" memiliki persentase yang semakin menurun mulai dari butir ke-1 sampai dengan butir ke-8. Gambar 3 menunjukkan persentase responden menjawab "ya" pada setiap butir FIES.

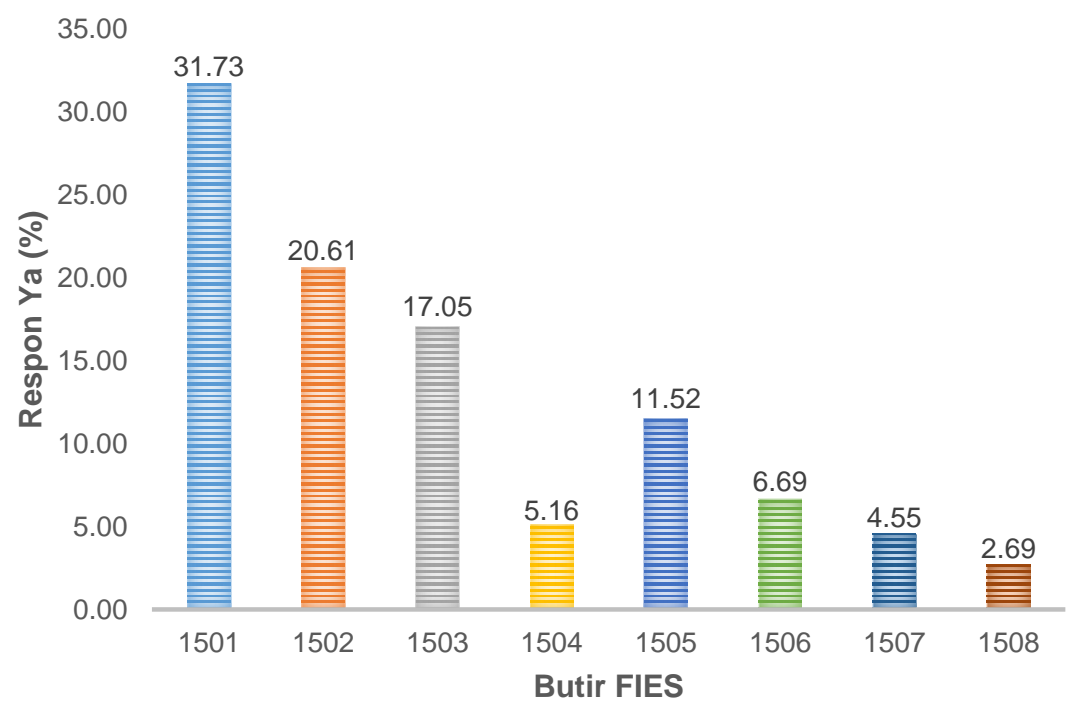

Gambar 3: Persentase responden menjawab "ya" pada setiap butir FIES.

Gambar 3 menunjukkan persentase butir 1504 (melewatkan satu kali waktu makan /skipped) memiliki persentase lebih kecil dibandingkan butir 1505 (kekurangan makan /ateless). Hal ini mengindikasikan ketidakkonsistenan responden dalam melaporkan pengalamannya. Konsisten dimaksud jika suatu butir direspon "ya" maka merespon "ya" pada semua butir yang kurang parah (Carlo Cafiero et al., 2014). Begitu pun respon "tidak" pada suatu butir maka akan merespon "tidak" pada butir yang lebih parah. Hal ini merupakan konstruk teori butir FIES.

Hasil pengolahan data mentah menunjukkan persentase terbesar dari total sampel yang tidak konsisten merespon pada butir 1505 (5.916 persen). Hal ini dapat dinyatakan bahwa terdapat 5.916 persen rumah tangga yang merespon "ya" pada butir 1505 namun merespon "tidak" pada butir 1504. Persentase kedua terbesar dari total sampel yang tidak konsisten merespon pada butir 1502 (3.062 persen). Hal ini mengindikasikan kurang tepatnya rumah tangga memahami butir 1501 dan 1504.

\subsection{Kurva Karakteristik Butir}

Hasil pengolahan RM yang menunjukkan hubungan tingkat kemampuan rumah tangga $\left(\theta_{j}\right)$ dengan peluang menjawab benar $(P(\theta))$ digambarkan oleh kurva karakteristik butir (Item Characteristics Curve/ICC). Nilai $\theta_{j}$ berada pada kontinum yang sama dengan penduga parameter skala keparahan butir $\left(\beta_{i}\right)$, yakni pada rentang nilai -4.2 sampai dengan 4.2. Peluang rumah tangga menjawab butir dengan benar $(P(\theta))$ bernilai diantara 0 sampai 1 . Penduga parameter $\beta_{i}$ menunjukkan skala kemampuan tertentu dari rumah tangga agar mempunyai peluang sebesar 50 persen menjawab ya pada 
butir. Garis vertikal pada $P(\theta)=0.5$ menunjukkan nilai skala keparahan butir mulai dari -3 sampai dengan 3. Keseragaman kemiringan kurva menunjukkan daya diskriminasi yang sama pada butir. Gambar 4 menunjukkan ICC butir FIES Indonesia.

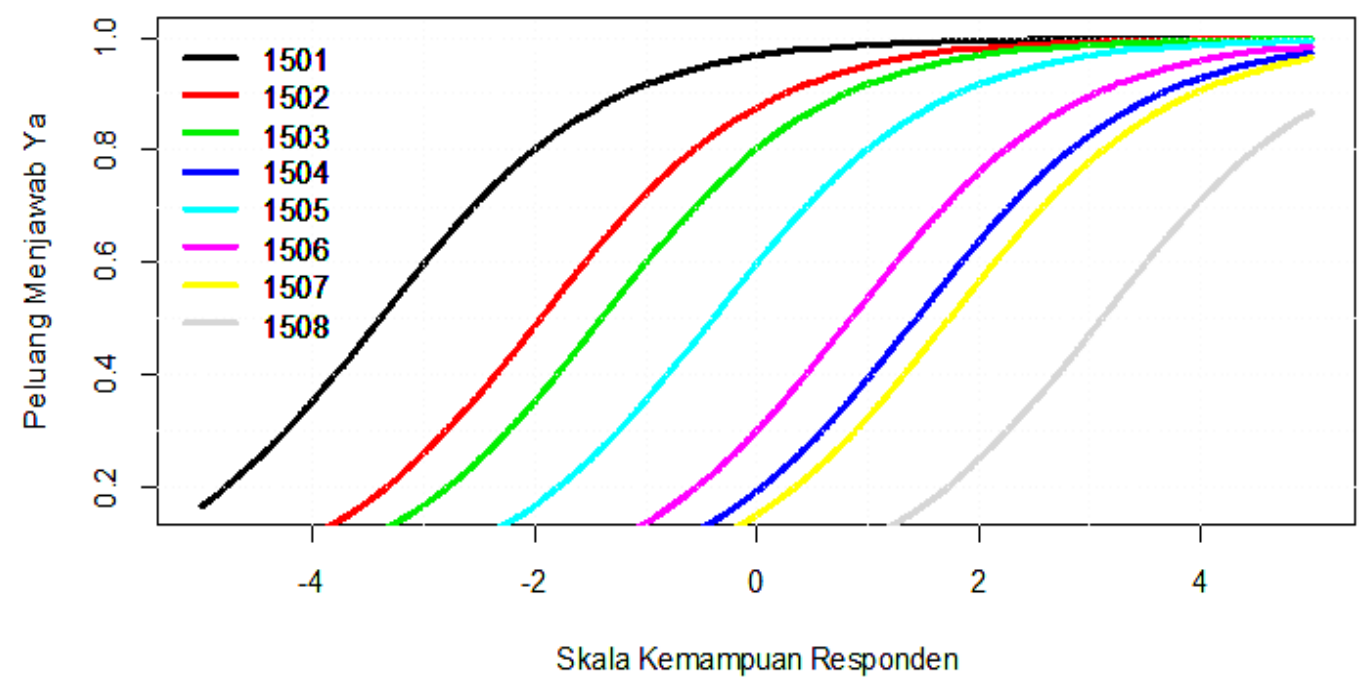

Gambar 4: Kurva Karakteristik Butir FIES.

Berdasarkan Gambar 4 diketahui butir 1501 (khawatir tidak akan memiliki cukup makanan/worried) sebagai butir termudah dan butir 1508 (seharian tidak makan apapun/wholeday) merupakan butir tersulit. Keduanya memiliki jarak terkecil dan terbesar dihitung dari titik awal kurva. Selain itu juga memperhatikan nilai $\widehat{\beta}_{l}$, yakni terkecil pada butir 1501 dan yang terbesar pada butir 1508. Ilustrasi ini bermakna bahwa skala keparahan butir semakin besar menunjukkan pengalaman rumah tangga yang semakin rawan pangan. Hal ini sesuai dengan teori konstruk butir FIES dimana kedelapan butirnya merupakan urutan pengalaman kerawanan pangan. Namun terdapat urutan yang berbeda pada butir 1504 (melewatkan satu kali waktu makan/skipped). Posisi kurva butir 1504 berada didekat butir 1507 (lapar tapi tidak mendapatkan makanan/hungry). Hal ini mengindikasikan perbedaan pemahaman pada butir 1504 .

\subsection{Analisis Keterandalan Internal Butir FIES}

\subsubsection{Skala Keparahan Butir dan Unidimensi}

Cafiero et al. (2018) mendefinisikan skala keparahan sebagai tingkatan yang menunjukkan dampak negatif pada rumah tangga ataupun kesejahteraan individu akibat ketidakmampuannya dalam mengakses makanan yang dibutuhkan. Memeriksa asumsi unidimensi melalui besaran infit dan outfit. Kedua statistik fit tersebut menunjukkan kekuatan dan konsistensi setiap butir dengan sifat latennya (Cafiero et al., 2016; Cafiero et al., 2018). Tabel 2 memberikan informasi adanya variasi skala kesukaran butir dan fit statistics. 
Tabel 2: Parameter skala keparahan butir FIES Indonesia dan statistik fit.

\begin{tabular}{lccccccc}
\hline Butir & $\begin{array}{c}\text { Skala } \\
\text { Keparah- } \\
\text { an Butir } \\
\text { Standar } \\
\text { Global }\end{array}$ & $\begin{array}{c}\text { Keparah- } \\
\text { an Butir } \\
\text { Indonesia } \\
\left(\widehat{\beta}_{l}\right)\end{array}$ & $\begin{array}{c}\text { Galat } \\
\text { Baku }\end{array}$ & $\begin{array}{c}\widehat{\beta}_{l} \\
\text { Infit }\end{array}$ & $\begin{array}{c}\text { Outfit } \\
\text { Kkala }\end{array}$ & $\begin{array}{c}\text { Indonesia } \\
\text { (Kalibrasi } \\
\text { dengan } \\
\text { Skala } \\
\text { Global) }\end{array}$ & $\begin{array}{c}\text { Selisih } \\
\text { Skala } \\
\text { Global } \\
\text { dengan } \\
\text { Skala } \\
\text { Indonesia }\end{array}$ \\
\hline 1501 & -1.223 & -3.391 & 0.010 & 1.153 & 3.186 & -1.673 & 0.450 \\
1502 & -0.847 & -1.948 & 0.009 & 0.970 & 1.579 & -0.961 & 0.114 \\
1503 & -1.106 & -1.397 & 0.010 & 0.776 & 0.830 & -0.689 & 0.416 \\
1504 & 0.351 & 1.439 & 0.015 & 1.037 & 1.201 & 0.709 & 0.358 \\
1505 & -0.312 & -0.394 & 0.011 & 0.861 & 0.812 & -0.195 & 0.117 \\
1506 & 0.507 & 0.850 & 0.013 & 0.912 & 0.896 & 0.419 & 0.088 \\
1507 & 0.755 & 1.738 & 0.017 & 0.834 & 0.815 & 0.857 & 0.102 \\
1508 & 1.876 & 3.110 & 0.025 & 1.031 & 2.288 & 1.534 & 0.342 \\
\hline
\end{tabular}

Tabel 2 menyajikan infit berkisar 0.776 sampai dengan 1.153, atau dapat dinyatakan bahwa semua butir berkinerja baik. Ballard et al. (2013) menyatakan bahwa skala pengukuran yang dibentuk oleh butir bernilai infit antara 0.8-1.2 menunjukkan terpenuhinya asumsi unidimensi. Dengan demikian dapat dinyatakan bahwa pengukuran FIES di Indonesia memenuhi asumsi unidimensi.

Outfit bernilai lebih dari 2 menunjukkan respon butir yang tidak menentu (pencilan). Namun Nord (2014) menyatakan outfit bernilai 2 atau lebih dapat diabaikan jika sampelnya kurang dari 0.25 persen responden. Perhatikan pada Tabel 2, butir 1501 dan 1508 memiliki outfit lebih dari 2. Namun, merujuk pada Gambar 2 diketahui persentase butir 1501 dan 1508 sebesar 31.3 dan 2.69 persen. Dengan demikian outfit butir 1501 menunjukkan data yang tidak menentu (pencilan) sedangkan outfit butir 1508 dapat diabaikan.

Pada Tabel 2 kolom skala keparahan butir hasil kalibrasi dengan skala referensi global menunjukkan nilai -2.0 sampai 2.0. Skala mendekati -2.0 menunjukkan butir yang mudah, sedangkan skala mendekati 2.0 menunjukkan butir tersebut sukar (Hambleton et al., 1991). Hal ini menunjukkan bahwa seluruh butir FIES berada dalam rentang yang diterima dan sesuai dengan konstruk teoritis butir FIES. Memperhatikan nilai galat baku yang kecil dari penduga parameter skala keparahan butir Indonesia $\left(\widehat{\beta}_{l}\right)$ maka dapat dinyatakan bahwa sampel menunjukkan akurasi yang baik dari sampel rumah tangga terhadap penduga parameter populasinya. 
Namun, berdasarkan kalibrasi skala butir FIES Indonesia dengan skala global diperoleh skala butir 1504 lebih besar dari butir 1505 serta nilai skalanya relatif dekat dengan skala butir 1507. Pada kolom selisih skala global dengan skala Indonesia diketahui butir yang bernilai lebih dari 0.35 yakni butir 1501, 1503 dan 1504. Hal ini menunjukkan bahwa ketiga butir tersebut termasuk butir unik karena dipahami berbeda-beda oleh beragam responden.

\subsubsection{Independensi Lokal}

Korelasi residual digunakan untuk memeriksa asumsi independensi lokal dari RM. Nord (2014) menyatakan korelasi residual bernilai $(>|0.4|)$ menunjukkan butir yang tidak independen. Tabel 3 menunjukkan korelasi residual pengukuran butir FIES.

Tabel 3: Korelasi residual butir FIES.

\begin{tabular}{llllllll}
\hline $\begin{array}{l}\text { Butir } \\
\text { FIES }\end{array}$ & 1502 & 1503 & 1504 & 1505 & 1506 & 1507 & 1508 \\
\hline 1501 & -0.022 & -0.082 & -0.128 & -0.129 & -0.091 & -0.091 & -0.115 \\
1502 & & 0.170 & -0.082 & -0.054 & -0.096 & -0.078 & -0.102 \\
1503 & & & -0.004 & 0.232 & 0.011 & 0.004 & -0.067 \\
1504 & & & & 0.048 & 0.046 & 0.090 & 0.034 \\
1505 & & & & & 0.101 & 0.088 & -0.027 \\
1506 & & & & & & 0.237 & 0.080 \\
1507 & & & & & & & 0.206 \\
\hline
\end{tabular}

Tabel 3 menunjukkan nilai korelasi residual antar butir berkisar di $|0.004|$ sampai $|0.237|$. Nilai tersebut kurang dari |0.4|, bahkan kurang dari |0.25|. Dengan demikian dapat dinyatakan bahwa data FIES Indonesia memenuhi asumsi independensi lokal yakni tidak terdapat korelasi antar butir FIES.

\subsubsection{Reliabilitas}

Koefisien reliabilitas hasil pengukuran RM menunjukkan interaksi antara responden dan butir secara keseluruhan dengan batasan 0.7. Pada penelitian ini diperoleh nilai koefisien reliabilitas flat sebesar 0.782 . Hal ini bermakna bahwa butir FIES secara keseluruhan sudah baik dalam mengukur kerawanan pangan. Koefisien reliabilitas hasil pengolahan data sampel seluruh rumah tangga (Indonesia) dan rumah tangga menurut subsampel dapat dilihat pada Tabel 4 . 
Tabel 4: Reliabilitas butir FIES Indonesia dan menurut subsampel

\begin{tabular}{lcc}
\hline Kelompok & $\begin{array}{c}\text { Reliabilitas } \\
\text { Flat }\end{array}$ & $\begin{array}{c}\text { Reliabilitas } \\
\text { Standar }\end{array}$ \\
\hline Indonesia & 0.782 & 0.684 \\
Perkotaan & 0.779 & 0.696 \\
Perdesaan & 0.786 & 0.674 \\
PPP60 & 0.784 & 0.691 \\
PPP $<60$ & 0.783 & 0.684 \\
\hline
\end{tabular}

Perhatikan nilai koefisien reliabilitas standar yang bernilai lebih kecil dari reliabilitas flat. Hal ini berlaku pada semua subsampel rumah tangga menurut wilayah tempat tinggal (perkotaan dan perdesaan) serta subsampel menurut pangsa pengeluaran rumah tangga (PPP 60 persen atau lebih dan PPP kurang dari 60 persen). Dengan demikian dapat dinyatakan secara keseluruhan model, data FIES Indonesia sudah sesuai konstruk teori dan arah kesalahan pengukuran tidak terpengaruh oleh objek yang diukur.

Namun, pengukuran FIES bertujuan untuk memantau kerawanan pangan yang dapat dibandingkan antar negara. Oleh karena itu, skala pengukuran FIES Indonesia divalidasi menggunakan prosedur kalibrasi butir dengan memilah sampel menurut wilayah tempat tinggal dan pangsa pengeluaran pangan.

\subsubsection{Kalibrasi Butir FIES dan Invariansi Parameter}

\section{Kalibrasi Simultan Parameter}

Kalibrasi simultan dilakukan serentak pada skala pengukuran, parameter tingkat kesulitan butir FIES dan kemampuan rumah tangga. Kalibrasi dilakukan dengan menyetarakan (equating) rataan (mean) dan simpangan baku (standar deviation). Gambar 5 merupakan hasil kalibrasi simultan yang mengidetifikasi butir FIES Indonesia sebagai butir umum (valid) dan butir unik (tidak valid). Butir 1501 dan 1504 teridentifikasi sebagai butir unik (tidak valid).

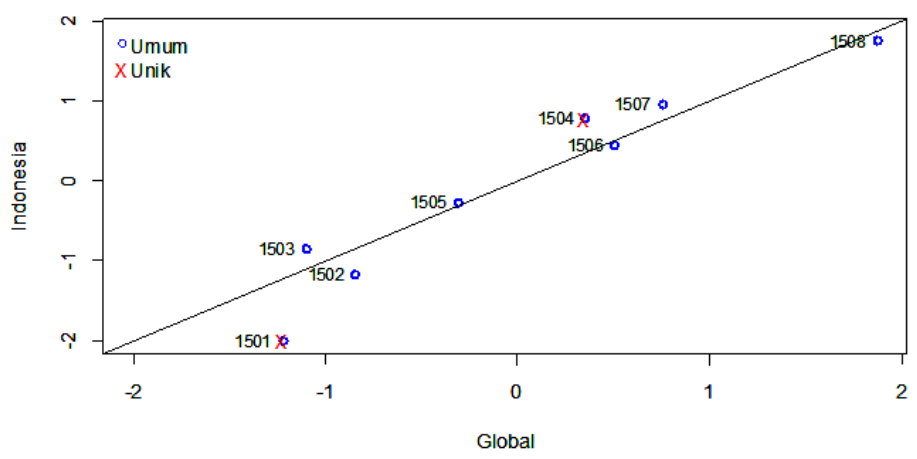

Gambar 5: Plot kalibrasi skala keparahan butir FIES Global dengan Indonesia 
Gambar 6 menunjukkan perbandingan plot kalibrasi simultan skala keparahan butir FIES Global dengan Indonesia menurut wilayah tempat tinggal (perkotaan atau perdesaan). Gambar 6(a) merupakan rumah tangga wilayah perkotaan yang menunjukkan butir unik meliputi butir 1501 dan 1504. Butir unik yang berbeda pada wilayah perdesaan (Gambar 6(b)) yakni butir 1503 dan 1508. Hal ini menunjukkan tidak terpenuhinya asumsi invariansi parameter pada rumah tangga menurut wilayah tempat tinggal.

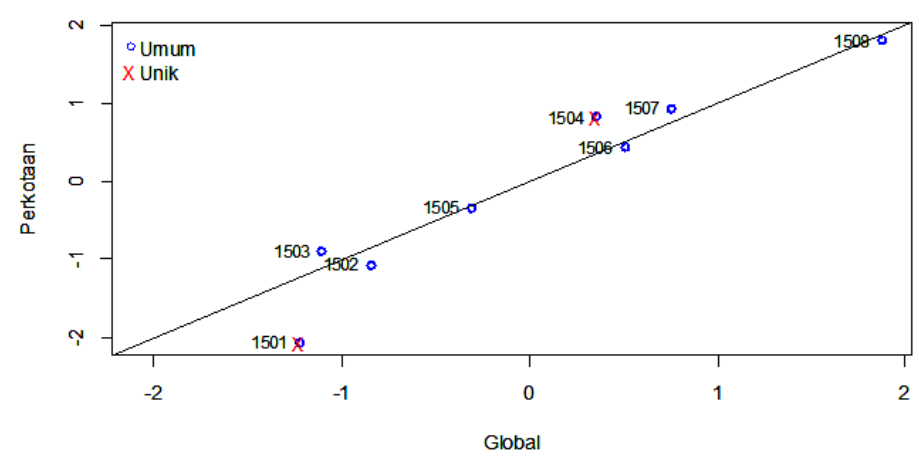

(a) Perkotaan

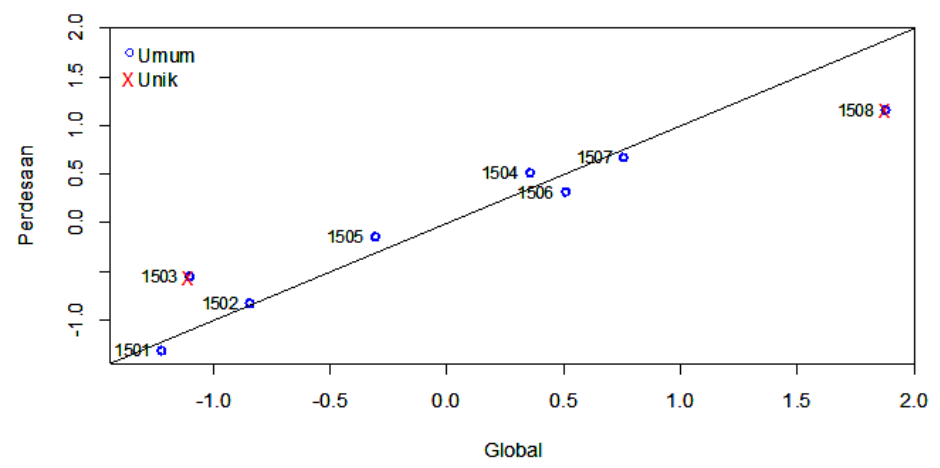

(b) Perdesaan

Gambar 6: Perbandingan plot kalibrasi simultan skala keparahan butir FIES Global dengan Indonesia menurut wilayah tempat tinggal.

Gambar 7 menunjukkan hasil kalibrasi simultan pengukuran FIES menggunakan subsampel menurut pangsa pengeluaran pangan. Gambar 7(a), yakni rumah tangga dengan pangsa pengeluaran pangan 60 persen atau lebih menunjukkan butir 1501 dan 1502 merupakan butir unik. Pada rumah tangga dengan pangsa pengeluaran pangan kurang dari 60 persen (Gambar 7(b)) menunjukkan butir 1501 dan 1504 merupakan butir unik. Terdapat perbedaan interpretasi pada butir 1502 dan 1504, hal ini menunjukkan tidak terpenuhinya asumsi invariansi parameter. 


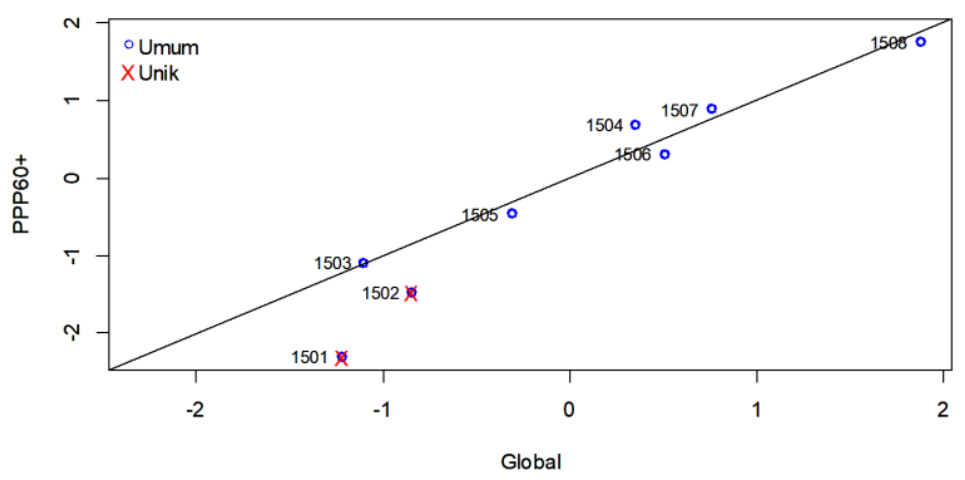

(a) Pangsa pengeluaran pangan 60 persen atau lebih

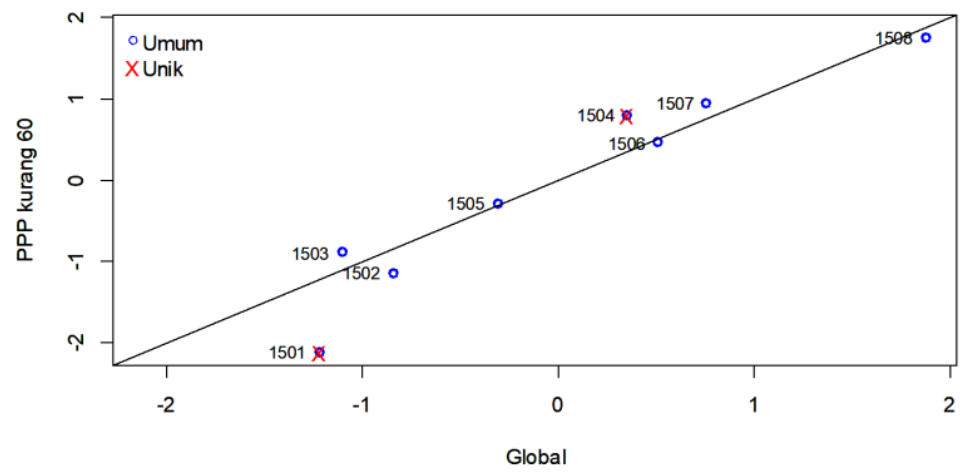

(b) Pangsa pengeluaran pangan kurang 60 persen

Gambar 7: Perbandingan plot kalibrasi simultan skala keparahan butir FIES Global dengan Indonesia menurut pangsa pengeluaran pangan

Berdasarkan analisis internal butir FIES, dapat dirangkum sebagai berikut:

- Pengukuran FIES di Indonesia sudah memenuhi asumsi unidimensi dan independensi lokal, namun butir 1501 diindikasikan pencilan.

- Koefisien reliabilitas pengukuran FIES Indonesia sebsar 0.78 menunjukkan secara keseluruhan merupakan model yang cukup baik.

- Prosedur kalibrasi skala butir FIES Indonesia terhadap skala referensi global menunjukkan perbedaan butir unik menurut sampel seluruh data dan subsampel. Hal ini menunjukkan tidak terpenuhinya asumsi invariansi parameter.

- Butir FIES Indonesia yang terindikasi butir unik adalah 1501 dan 1504. Namun terdapat perbedaan butir unik menurut subsampel wilayah perdesaan (butir 1503 dan 1508). Perbedaan juga ditemui pada butir unik menurut subsampel pangsa pengeluaran pangan 60 persen atau lebih yaitu butir 1502 .

\subsection{Analisis Eksernal Butir FIES}

Analisis eksternal pengukuran FIES dilakukan dengan menganalisis korelasi antara agregasi tingkat kabupaten pada setiap butir FIES yang dijawab "ya" dengan karakteristik determinan kerawanan pangan rumah tangga. Gambar 8 menunjukkan sebagian besar koefisien korelasi memiliki arah korelasi positif. Hal ini berarti semakin 
besar persentase rumah tangga menjawab "ya" pada butir FIES berkorelasi dengan semakin besar persentase rumah tangga yang sesuai dengan karakteristik akses fisik, sosial dan ekonomi rumah tangga rawan pangan. arah korelasi negatif ditunjukkan peubah X10 dan X11 (Gambar 8(c)). Hal ini termasuk relevan, dimana semakin besar persentase rumah tangga menjawab "ya" pada butir FIES berkorelasi dengan semakin kecil pengeluaran perkapita rumah tangga dan semakin kecil persentase rumah tangga penerima transfer dari pihak diluar anggota rumah tangga.

Memerhatikan besaran koefisien korelasi antara butir FIES dengan karakteristik rumah tangga rawan pangan ditunjukkan butir 1501 lebih kecil dari butir 1502 dan butir 1504 lebih kecil dari butir 1505. Berdasarkan konstruk teori FIES, respon yang semakin kecil pada butir FIES yang semakin parah, berarti seharusnya nilai koefisien korelasi 1501 lebih besar dari butir 1502 dan butir 1504 lebih besar dari butir 1505.

Butir 1508 menunjukkan arah korelasi yang berbeda dengan butir FIES lainnya yakni pada peubah $\mathrm{X} 1, \mathrm{X} 5, \mathrm{X} 6, \mathrm{X} 7$ dan $\mathrm{X} 10$. Namun merujuk pada proporsi respon butir 8 yang lebih kecil dari 0.25 dari sampel rumah tangga maka hal ini dapat diabaikan. Dengan demikian, dapat dinyatakan bahwa butir yang tidak valid ditunjukkan oleh butir 1501 dan 1504. Hal ini sejalan hasil analisis internal butir FIES.

Berdasarkan Gambar 8 diketahui koefisien korelasi terbesar ditunjukkan butir 1502 (pengalaman tidak dapat menyantap makanan sehat dan bergizi), butir 1503 (pengalaman menyantap sedikit jenis makanan) dan butir 1505 (makan lebih sedikit dari yang dibutuhkan) dengan peubah X2 (jumlah anggota rumah tangga berusia 0-4 tahun). Hal ini mengindikasikan pada rumah tangga yang semakin banyak memiliki anak berusia 0-4 tahun mempunyai persentase yang semakin besar untuk menjawab "ya" pada ketiga butir tersebut. 


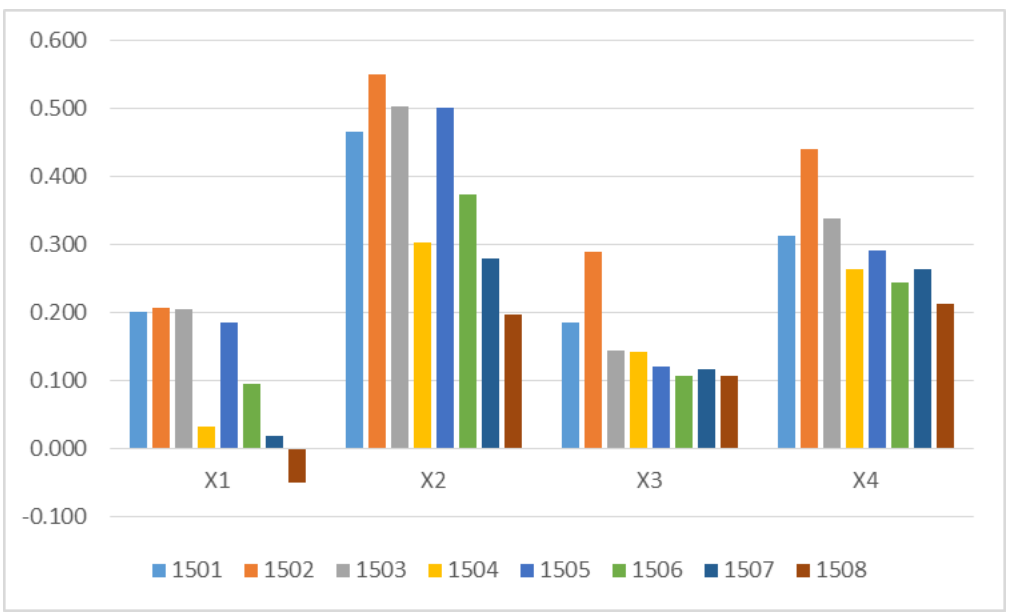

(a) karakteristik akses fisik

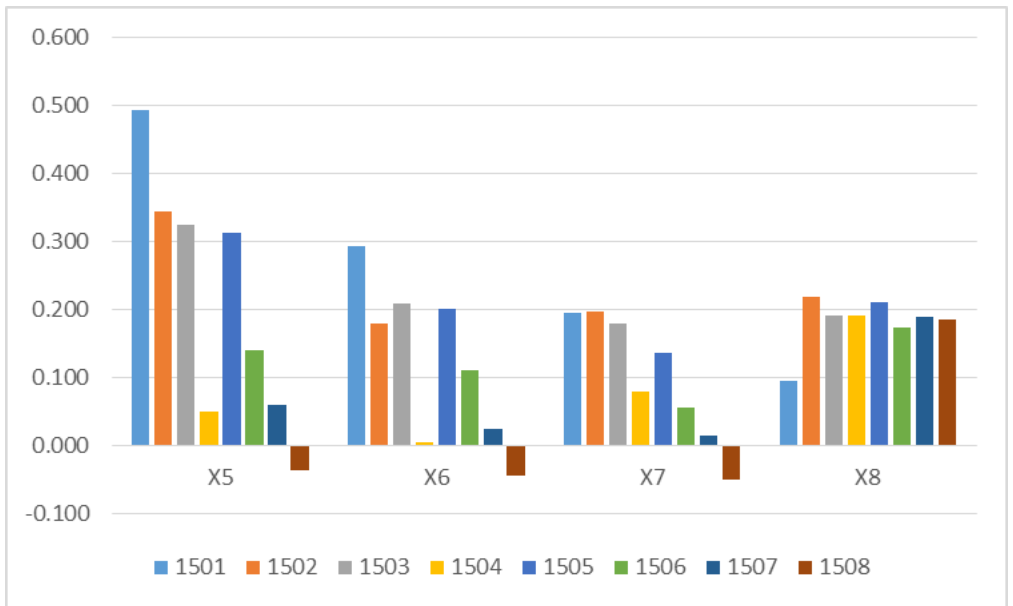

(b) karakteristik akses sosial

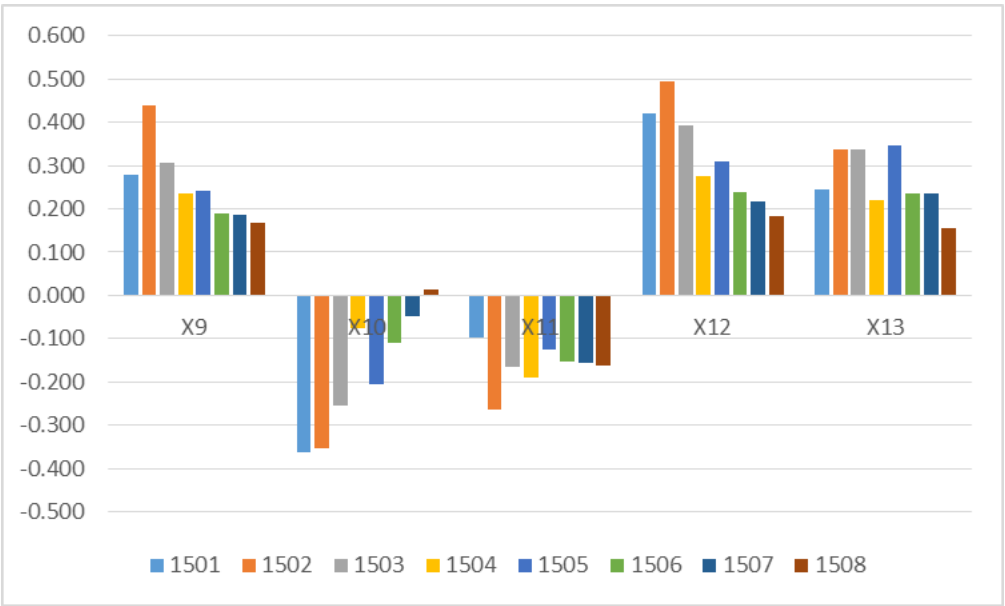

(c) karakteristik akses ekonomi

Gambar 8: Korelasi butir FIES dengan karakteristik akses fisik, sosial dan ekonomi rumah tangga rawan pangan. 


\section{Simpulan dan Saran}

\subsection{Simpulan}

Analisis internal pengukuran FIES di Indonesia mengidentifikasi validitas menggunakan Rasch Model. Hasilnya sudah memenuhi asumsi unidimensi dan independensi lokal. Namun butir 1501 teridentifikasi pencilan, menunjukkan beragamnya interpretasi rumah tangga terhadap butir tersebut. Koefisien reliabilitas bernilai 0.78 menunjukkan pengukuran FIES Indonesia sudah sesuai dengan konstruk teori FIES. Nilai yang sama diperoleh dari pengukuran reliabilitas pada subsampel wilayah tempat tinggal dan pangsa pengeluaran pangan. Hal ini menunjukkan konsistensi pengukuran FIES.

Prosedur kalibrasi simultan skala butir FIES Indonesia terhadap skala referensi global (global reference scale) menunjukkan perbedaan butir unik menurut sampel seluruh data dan subsampel. Butir FIES Indonesia yang terindikasi butir unik adalah butir 1501 dan 1504. Namun terdapat perbedaan butir unik menurut subsampel wilayah perdesaan yang meliputi butir 1503 dan 1508. Perbedaan juga ditemui pada butir unik menurut subsampel pangsa pengeluaran pangan 60 persen atau lebih yaitu butir 1502. Hal ini menunjukkan tidak terpenuhinya asumsi invariansi parameter.

Analisis eksternal pengukuran FIES mengidentifikasi bahwa butir 1501 dan butir 1504 sebagai butir yang tidak valid (butir unik). Hal ini ditunjukkan dengan besaran koefisien korelasi butir 1501 lebih kecil dari butir 1502 dan butir 1504 lebih kecil dari butir 1505. Selain itu, diperoleh koefisien korelasi terbesar antara butir 1502, 1503 dan 1505 dengan peubah X2. Hal ini mengindikasikan pada rumah tangga yang semakin banyak memiliki anak berusia 0-4 tahun mempunyai persentase yang semakin besar untuk menjawab "ya" pada ketiga butir tersebut.

\subsection{Saran}

Perlu dilakukan kajian adaptasi linguistik pada butir unik (yang tidak valid). Kajian ini bertujuan memperbaiki kalimat yang membentuk butir agar dipahami sama oleh berbagai karakteristik rumah tangga. Harapannya dapat mengurangi informasi tidak konsisten dan membantu menjamin keterbandingan antar negara. Batasan dibutuhkan untuk mendefinisikan khawatir pada butir 1501 dalam konteks tidak akan mendapatkan makanan. Penggunaan tambahan kata diperlukan pada butir 1504. Sebagai saran, ditambahkan kata tidak bisa makan atau tidak mendapatkan makanan sesuai kebiasaan waktu makannya.

Penelitian berikutnya dapat melengkapi analisis butir FIES menggunakan analisis spasial berdasarkan peubah determinan kerawanan pangan. 


\section{Daftar Pustaka}

Alexandri, C. (2015). Population food security assessment: A methodological approach. Agrarian Economy and Rural Development-Realities and Perspectives for Romania. 6th Edition of the International Symposium, 2-8. Bucharest: The Research Institute for Agricultural Economy and Rural ....

Ballard, T. J., Kepple, A. W., \& Cafiero, C. (2013). The food insecurity experience scale: development of a global standard for monitoring hunger worldwide. Retrieved from http://www.fao.org/economic/ess/ess-fs/voices/en/

Bond, T., \& Fox, C. M. (2015). Applying the Rasch model: Fundamental measurement in the human sciences. Routledge.

[BPS] Badan Pusat Statistik. (2017a). Indikator tujuan pembangunan berkelanjutan Indonesia. Jakarta (ID): Badan Pusat Statistik.

[BPS] Badan Pusat Statistik. (2017b). Statistik kesejahteraan rakyat. Jakarta (ID): Badan Pusat Statistik.

Cafiero, C., Nord, M., Viviani, S., Del Grossi, M. E., Ballard, T., Kepple, A., \& Nwosu, C. (2016). Methods for estimating comparable prevalence rates of food insecurity experienced by adults throughout the world. Rome (IT): Food and Agriculture Organization of the United Nations.

Cafiero, C, Melgar-Quinonez, H. R., Ballard, T. J., \& Kepple, A. W. (2014). Validity and reliability of food security measures. Annals of the New York Academy of Sciences, 1331(1): 230-248.

Cafiero, C, Viviani, S., \& Nord, M. (2018). Food security measurement in a global context: The food insecurity experience scale. Measurement, 116: 146-152.

[DKP] Dewan Ketahanan Pangan. (2015). Peta Ketahanan dan Kerentanan Pangan Indonesia Tahun 2015. Jakarta (ID): Kementerian Pertanian RI.

Duffy, P. A., \& Zizza, C. A. (2016). Food insecurity and programs to alleviate it: what we know and what we have yet to learn. Journal of Agricultural and Applied Economics, 48(1): 1-28.

[FAO] Food and Agriculture Organization. (2009). Draft declaration of the world summit on food security. Retrieved from http://www.fao.org/fileadmin/templates/wsfs/Summit/Docs/Declaration/WSFS09_D raft_Declaration.pdf

[FAO] Food and Agriculture Organization. (2018). Using the Food Insecurity Experience Scale (FIES). Retrieved from http://www.fao.org/elearning/\#/elc/en/course/SDG212

Hambleton, R. K., Swaminathan, H., \& Rogers, H. J. (1991). Fundamentals of item response theory. Sage.

Magaña-Lemus, D., Ishdorj, A., Rosson, C. P., \& Lara-Álvarez, J. (2016). Determinants of household food insecurity in Mexico. Agricultural and Food Economics, 4(1): 10. 
Nord, M. (2014). Introduction to item response theory applied to food security measurement: Basic concepts, parameters, and statistics (Vol. 2014). Rome (IT): FAO.

Smith, M. D., Rabbitt, M. P., \& Coleman-Jensen, A. (2017). Who are the world's food insecure? New evidence from the Food and Agriculture Organization's food insecurity experience scale. World Development, 93: 402-412.

Sundari, I., \& Nachrowi, N. D. (2015). Analisis Raskin dan Ketahanan Pangan Rumah Tangga di Indonesia (Analisis Data Susenas 2011). Jurnal Ekonomi Dan Pembangunan Indonesia, 15(2): 121-143.

Wambogo, E. A., Ghattas, H., Leonard, K. L., \& Sahyoun, N. R. (2018). Validity of the food insecurity experience scale for use in sub-Saharan Africa and characteristics of food-insecure individuals. Current Developments in Nutrition, 2(9): nzy062.

Wardani, A. S. (2018). Determinan Ketahanan Pangan Dan Gizi Rumah Tangga Petani Indonesia Di Kawasan Pedesaan [disertasi]. Surabaya (ID): Universitas Airlangga. 